\title{
Modernization of employment structures enhancing socioeconomic cohesion in the European Union countries
}

\author{
Magdalena Cyrek \\ Department of Microeconomics, University of Rzeszón \\ Poland \\ Email:myrek@ur.edu.pl
}

\begin{abstract}
This study investigates the relative efficiency of the $28 \mathrm{EU}$ countries when transforming employment in four different sectors into socioeconomic cohesion. It evaluates the cohesive effects from modernization processes into a service and knowledge-based economy basing on the most recent data (generally describing the 2015 year). Results for the economies are derived from the usage of DEA method assuming non-radial transformations in an input-oriented model (CCRNR). Socioeconomic cohesion is researched in its two dimensions: wealth distribution and social networks. Thus, a classical area of research on efficiency with productive results is browsed into a social field. It is of special importance in the post-crisis period when economic divergence, growing social tensions as well as strong diversification in public social support within the EU countries is observed. The main findings support the view that modern changes in employment structures are favourable for socioeconomic cohesion, as the highest efficiency is typical for knowledge-intensive services and consecutively for less knowledge-intensive services. The poorest results are gained in low and mediumlow technology manufacturing and just a little better - in high and medium-high technology manufacturing. The study provides some arguments into the discussion about de- and reindustrialization. We have found that the EU policy enhancing cohesiveness should mainly support the processes of KIS development as well as human capital creation and its economic engagement.
\end{abstract}

Received:

June, 2017

1st Revision:

August, 2017

Accepted: September, 2017

DOI:

$10.14254 / 2071-$ $8330.2017 / 10-3 / 14$

Keywords: sectors, social efficiency, DEA, the EU countries.

JEL Classification: I30, J20, J21, J24, O10, O11, O14, O15, O40

\section{INTRODUCTION}

Structural changes and reallocation of employment in a process of socioeconomic development have long been the issue of interest for researchers. The classical three-sectoral theory by Fisher (1935), Clark (1940) and Fourastié (1949) constitutes a starting point for such analysis, however, as today structural modernization is described by deindustrialization and knowledge-based economy development (see De Backer et al., 2015; Peneder et al., 2001), new sectoral growth poles (see Perroux, 1955) are being identified. 
Traditionally, structural features of an economy are considered in terms of its results concerning unemployment and earnings as well as for productivity and convergence (e.g., De Serres et al., 2002; Diewert, 2015; Maudos et al., 2000; Margaritis et al., 2007). The role of each sector is evaluated by its influence on such economic phenomena and thus optimal kind of specialization is searched for (e.g., McCann and Ortega-Argilés, 2011). Despite that effort, comparatively little attention has been paid to exploring the effects of employment structures on socioeconomic cohesion and its different dimensions. Some exceptions are constituted by the studies in a stream derived from Kuznets' work (1966) on structural implications for inequality (e.g., Paunov, 2013; Loayza \& Raddatz, 2006; Ghani \& Kharas, 2010). However, there is a serious gap in the analysis of implications of the sectoral distribution of employment for compound dimensions of socioeconomic cohesion. Some studies (e.g., Kaasa, 2016; Hoyman et al., 2016) adopt an inverse approach as the growing interest is being paid to the influence of social capital and social networks on different aspects of development.

This study contributes to the literature by examining the efficiency of sectoral employment in achieving socioeconomic cohesion. Cohesion is understood here as a multidimensional phenomenon that constitutes a desirable goal of socioeconomic processes. It is analysed considering its two aspects that are directly connected with an employment issue: wealth distribution and social networks. It is in line with the literature about social cohesion where distributive (economic, negative) and relational (structural, positive) dimensions are often specified (e.g., Loktieva, 2016; Kosiel, 2012; Andrews, 2014). This article offers a preliminary evaluation of the relationship between structural modernization and two-dimensional cohesion reflected by income equality and satisfaction with personal relationships. Thus, the novelty of research is to extend a traditional approach to effects of structural changes for a labour market, productivity and economic growth to a new field of social relationships with economic background. This approach is focused on integrated socioeconomic development that goes out of strictly economic limitations and goals specified in terms of production level. As problems of modern advanced economies are usually attributed to the materialization of developmental goals there is an urgent need to go beyond such an attitude.

The aim of the current study is to assess the cohesive effects of employment in different economic sectors. We are also going to fulfil the task of identifying sectors that are the most favourable for socioeconomic cohesion. An attempt to evaluate the processes of modernization is taken as well. Findings may thus constitute a base for structural (industrial) policy consistent with the main strategic goals of the European Union.

The research is done considering the $28 \mathrm{EU}$ countries. A relative efficiency of each country performance when transforming employment into socioeconomic cohesion is compared by means of nonparametric DEA method in a form of CCR-NR input-oriented model. Data are extracted from the Eurostat database and present the most actual statistics available at the time of this study preparation. Generally, we describe the 2015 year, however, the subjective dimension of cohesion covers the 2013 year as research about this aspect of well-being in the EU have not been repeated as for now. Even though the detailed statistics differ in time, both sectoral changes, as well as social ones, are rather long-term phenomena and one can expect only minor changes every year. Thus, the analysis presents a current situation in the EU countries considering its structural features in terms of employment, distribution and social relationships.

Main restrictions of the research are connected with an aggregated level of the analysis. Firstly, crosscountry comparisons within the EU do not allow catching interregional or local differences in both: level of modernization and socioeconomic cohesion. On the other hand, the conclusions are limited to the European environment alone. Nevertheless, the EU countries' group is homogenous enough to search for benchmarks and formulate indices for socioeconomic policy. Secondly, modernization processes are specified in the research by four-sectoral employment structure, while much more detailed activity 
disaggregation is to be used to find fields of optimal specialization. However, we go beyond the classical three-sectoral theory and take into account the ongoing processes of tertiarisation and increasing knowledge-intensity. Thirdly, socioeconomic cohesion is described by two dimensions only, although it is a much more compound phenomenon. We have focused our attention on the dimensions that mix economic and social issues as the ones directly connected with employment.

These restrictions are connected with the availability of comparable statistical data and the DEA method limitations in terms of proportion between a number of variables and objects used for comparisons. However, the research allows formulating some preliminary conclusions about the employment in different sectors and its cohesive results. These conclusions can become the starting point for more detailed analyses developed in three directions mentioned above.

This article is organised as follows. Section 1 presents the theoretical background behind modernization issues, while Section 2 discusses the concept of socioeconomic cohesion. Section 3 introduces the data and presents the research method. Section 4 discusses the results and Section 5 concludes.

\section{LITERATURE REVIEW}

\subsection{Modernization as a field of academic debate}

Modernization is a concept adopted in many scientific disciplines and generally is understood as a process of continuous improvement, updating and upgrading (Woźniak, 2012a, p. 73-75). An essence of modernization may be described as a change that improves the efficiency of actions and delivers benefits for society (Kleer, 2012, p. 111).

Modernization may be analysed concerning changes in employment structures. One from many dimensions describing employment structures is constituted by sectoral or branch relations. In such a way modernization is characterized by the development of industries found as sectoral poles (Perroux, 1955), which dynamically gain shares in the economy.

A modern phase of structural changes in developed countries is featured by both service-based and knowledge-based model. It can be described not only by deindustrialisation, tertiarisation, and servitisation of the economy (see e.g. De Backer et al., 2015) but also by quaternalisation processes (Peneder et al., 2001). A special characteristic of the model is high dynamics of employment, production as well as productivity of branches that engage human capital, use modern technologies (mainly information and communication technologies - ICT), participate in innovation networks and invest in such non-material resources. Structural modernization may thus be understood as the development of high-tech and knowledge-intensive branches.

This pattern of changes has been observed in the EU as employment in services, mainly in knowledgeintensive services (KIS) systematically increases its shares. Even the last economic crisis did not stop the process. As in 2008 year 37\% of the employed were engaged in KIS, their share was 39,9\% in 2015 year. It was connected mainly with a decrease of employment share in low and medium-low technology manufacturing ( $11,2 \%$ in 2008 year and 9,7\% in 2015 year) (Eurostat, http).

Discussions about structural changes and modernization often centre on specialization. Academic debates are held concerning optimal level of specialization versus diversification and scientists try to identify the most favourable fields to specialize in. Within such a debate a concept of smart specialization has appeared. As McCann and Ortega-Argilés (2011) pointed out it originated in the attempts to identify reasons for the productivity gap between the US and Europe. The researchers referred to differences in industrial structure, which in the EU is characterised by more traditional, middle and low-tech sectors. Their findings 
suggest that the productivity gap is a result of the slower emergence of the knowledge-based economy in Europe (McCann \& Ortega-Argilés, 2011, p. 5-6). The discussion about optimal specialization leads to assessments made on the influence of specialization on economic development. In such a context research done by Kemeny and Storper (2014) reveals that growing absolute specialization is positively linked to wages, which they take as an approximation of labour productivity. However, they suggest that the important issue is connected rather with "what" to specialize in (Kemeny and Storper, 2014, p. 13). In line with such findings is research conducted by Wolman, Stokan, and Wial (2015) who claim that strong complementarity between manufacturing and advanced services makes it an unlikely path to success to focus on advanced services, health care, or higher education jobs in the absence of manufacturing (Wolman et al., 2015a, p. 110). A similar view is presented by Antonelli and Fassio (2016) whose analysis confirms that in advanced economies the specialization in knowledge-based activities (namely: knowledge-intensive business services - KIBSs and knowledge-intensive manufacturing - KIM) substituted for the previous specialization in mass manufacturing activities supporting the increase of total factor productivity. They stress the complementarity between the KIBSs and a thinner but highly skilled KIM industry which is necessary for the knowledge generation mechanisms based on user-producer interactions at work (Antonelli \& Fassio, 2016, p. 3, 5, 13).

Traditionally structuralists conduct research about the influence of structural changes on employment level, deal with problems of unemployment and sometimes are interested in earnings. Such group of view is represented by De Serres, Scarpetta and De la Maisonneuve (2002), who connect the trend decline in the aggregate wage share observed in Europe and the USA with changes in the sectoral composition of the economy (De Serres et al., 2002, p. 2). Wolman, Wial, and Hill (2015) find that deindustrialization has serious negative consequences for employment and earnings (Wolman et al., 2015b, p. 99, 101). Wolman, Stokan, and Wial (2015) indicate that declines in manufacturing resulted in a movement of jobs from relatively highwage to relatively low-wage industries and thus a decline in earnings per jobs (Wolman et al., 2015a, p. 102). On the other hand, Drucker's findings of the relationship between regional industrial structure and employment change suggest that less competitive industrial structures at the regional scale are negatively associated with employment change and greater regional structural concentration in the manufacturing sector substantially increases the expected job loss (Drucker, 2014, p. 17). As there is a common agreement about the importance to study relations between deindustrialisation and labour market, an interesting point was made by Lechevalier. He claims that these kinds of studies cannot be restricted to changes in the employment structure but have to also include the analysis of various indicators of job "quality" (e.g. wage inequalities), which have been relatively neglected by the literature or studied partially and separately (Lechevalier, 2015, p. 405). This attitude concerns not only the strictly economic, countable dimension of structural modernization which is predominant in the academic debate but pays attention to a broader vision of a man as a member of society that forms internal interdependencies and mutual relations.

To some extent, this gap is fulfiled by studies about structural implications for inequality. Paunov takes such approach and points out that economic shift towards modern sectors may cause temporary increases in inequality. She concludes that a condition to minimise inequality is knowledge spillovers among sectors (Paunov, 2013, p. 7-28). Influence of sectoral decomposition of growth on poverty was the issue researched by Loayza and Raddatz (2006), who stress an alleviating role of labour-intensive sectors, such as agriculture, construction, and industry. On the other hand, Ghani and Kharas (2010) claim that for developing countries growth in the service sector is more closely correlated with poverty reduction than is growth in agriculture (Ghani \& Kharas 2010, p. 2-4). The search for sectors with positive distributional and social outcomes is, however, relatively rare in academic literature. It is thus an important way of thinking that we develop further within the study. 
In parallel to problems of employment and earnings, academic debate is strongly focused on the contributions of structural changes to productivity growth and convergence. Concerning productivity Diewert (2015) provides some decompositions of labour productivity growth and total factor productivity (TFP) growth into sectoral effects. He finds that the productivity growth rate depends on the sectoral productivity growth rates, real price changes and changes in sectoral labour input shares (Diewert, 2015, p. 367). Within the convergence stream, O'Leary finds that structural change between agriculture, industry, and services had a convergent effect between EU regions. While increasing the degree of sectoral disaggregation, the findings suggest that agriculture is a major source of the observed convergent effect (O'Leary, 2006, p. 1). In another study, O'Leary and Webber also conclude about the importance of structural change for growth and convergence in EU regions (O'Leary and Webber, 2015, p. 1). Such view is also supported by Maudos, Pastor, and Serrano (2000), who prove that structural changes are more important for regional convergence in Spain than intra-sectoral efficiency changes. While comparing the efficiency of different sectors, they find the lowest in agriculture and energy and the highest and similar in manufacturing, services, and construction (Maudos et al., 2000). Supporting this view are also research conducted by Sassi (2011) who suggests that the shift effect dominates aggregate productivity growth in European regional convergence (Sassi, 2011, p. 112). On contrary, Badunenko and Romero-Ávila (2015) claim that more important for aggregate productivity growth are sectoral efficiency changes (especially in agriculture and manufacturing) than structural shifts (Badunenko and Romero-Ávila, 2015). Moreover, the analysis conducted by Kucera and Roncolato (2012) shows that for an economic growth within-sector effects are more important than employment reallocation effects (Kucera and Roncolato 2012, p. 4-9). Margaritis, Färe, and Grosskopf (2007) also find that the contributions of sectoral to aggregate productivity growth for all OECD countries is predominantly driven by within sector effects with very little contribution emerging from sectoral shifts. For most OECD countries the major contributors to aggregate productivity growth are the high-tech manufacturing and tertiary sectors (Margaritis et al., 2007, p. 103). Generally, at the aggregate level, most of the authors find that contribution of services to total growth is higher than industry's contribution (see e.g. Ghani et al., 2012, p. 1). Thus, the convergence debate also focuses on the search for the optimal sectoral relations pointing out its effects in aggregate production level. Social results of economic structures are somehow left out of the discussion. We thus find it as an important challenge to pay attention to this neglected area of research.

\subsection{Concept of socioeconomic cohesion}

A term socioeconomic cohesion is often perceived as having strong policy roots, practical implications and thus is ambiguously or even ill-defined as a scientific concept and an analytical construct to explain social, political and economic changes (Hulse \& Stone, 2007, p. 109; Dekker \& Bolt, 2005, p. 2448). Hence, it is a scientific necessity to discuss its understanding and decide about operationalization.

Considering its etymology, cohesion means a similarity of features of objects under comparisons, similarity of processes and integration of the objects by creating some ties (Woźniak, 2012b, p. 13). It can be defined as a feature of a group in which elements are strongly integrated and understood as some kind of unity in opposition to disintegration and division (Wojnar, 2011, p. 69).

Social cohesion is shaped as a result of ties between an individual and society (Wojnar, 2011, p. 69) and is frequently seen as the equivalent of social networks, although it is much more compound phenomenon (Dekker \& Bolt, 2005, p. 2448). The concept of social cohesion is deployed as means for understanding the capacity of a community to reproduce itself in the long run and societies are cohesive when aggregate-level conditions are producing positive membership attitudes and behaviors (Andrews, 2014, p. 706). 
The concept of social cohesion has a strong theoretical base. Andrews (2014) mentions the social disorganization theory by Shaw and McKay, the theory of distributive justice by Rawls and the theory of democratic public administration by Fredrickson (Andrews, 2014, p. 707). Most authors (e.g. Hulse \& Stone, 2007, p. 109) cite Durkheim's studies formed at the end of the 19th century. Wojnar (2011, p. 69-71) specifies even five groups of definitions of cohesion, all having the strong theoretical background.

In a political context, Hulse and Stone (2007) emphasize differences between countries with different institutional settings in understanding a social cohesion concept. In liberal welfare countries, social cohesion refers to the social relations, networks, and associations and incorporates the idea of social capital derived from Putnam's work. In Europe, social cohesion is referred to the reduction of differences, cleavages, and inequalities and is close to the ideas associated with social exclusion. There is also a third dimension, in which social cohesion refers to the norms underlying the ties that bind people together (Hulse \& Stone, 2007, pp. 119, 123-124).

We understood the concept of social cohesion as a developmental goal and final effect of social pursuits. In fact, in the EU it is a key policy aim, both in terms of enhancing the equity and in terms of the harmoniousness of the relationships between different social groups (Andrews, 2014, p. 705). It is reflected in many fundamental EU legal acts and strategic documents such as "Europe 2020" and assumes its fundaments in inclusive growth and employment. Importance of the cohesion concept seems to be induced by the general pursuit of every individual to live in a friendly social environment without distracting tensions between individuals and groups. Such tensions often occur in periods of economic downturns having some material stems and without appropriate state interventions may bring conflicts and aggression. Meanwhile, since the appearance of the first results of the financial crisis in 2008 year the public support in the EU were limited reflecting a crisis of the welfare state. Diversification processes within the EU have been observed in both the economic as well as the social sphere (see e.g. Kohl, 2015; Mucha-Leszko, 2016). Moreover, migration problems have caused that the social tensions are more flagrant and the situation proves timeliness of the cohesion issue.

Cohesion as a multidimensional concept is analysed concerning different aspects of social life. Kearns and Forrest (2000) distinguish five key aspects of social cohesion such as: common values and civic culture; social order and social control; social solidarity and reductions in wealth disparities; social networks and social capital; place attachment and identity. It is a common attitude of researchers to focus on some of the listed dimensions (e.g. Andrews, 2014; Dekker and Bolt, 2005) and it is adopted in the study as well by paying a special attention to the lack of wealth disparities and satisfying social networks as features of cohesive society. Both dimensions are shaped during employment, where one can improve their material status as well as interact with other people.

Cohesion may be as well described on two axes presented by Berger-Schmitt: one that eliminates differences, second that strengthens and improves relations in society (Kosiel, 2012, p. 30) also known as distributive (economic) and relational (structural) dimensions (Loktieva, 2016, p. 148-150). The first one can be understood as a negative approach, while the second as a positive one. This kind of differentiation may be a useful point to fulfil a present analysis.

Moreover, social cohesion is described in both objective and subjective terms (Andrews, 2014, p. 707). A system of objective indicators proposed in Laeken covers results of processes aimed at achieving cohesion in such fields as incomes, labour market, education and health (Kosiel, 2012, p. 27, 32-33). On the other hand, subjective indicators describe positive social attitudes and perceptions attributed to a cohesive society. In the paper we focus not only on an objective and negative (based on identifying differences) way to assess a macroeconomic level of cohesion, which is characteristic of the Laeken approach, but we complement it by subjective assessment of social integration. 
Drawing from the most of these views we operationalize the idea of social cohesion as one that covers at least two essential aspects:

- equality in wealth distribution, which can be perceived as an objective feature of society, however, supported by the shared norms and values of solidarity and general pursuit to eliminate differences;

- positively perceived social relationships, networks, ties and interactions within communities as subjective ones bringing satisfaction and fulfilment.

The first one is usually assessed by comparisons of such indicators as Gini coefficient or income quintile share ratio as well as a share of the population at risk of poverty, material deprivation or unemployment. The social relationships' aspect may be evaluated by objective features of society like civic participation, non-for-profit actions or subjective assessment of trust and personal ties.

Empirically observed changes in social cohesion in the EU suggest that in spite of some political efforts the situation has not improved at least since the last crisis occurrence. The level of income inequalities seems to be stable or even grows (Gini's value was 30,9 in 2008 year and 31 in 2015 year; quintile ratio: 5 and 5,2 respectively) such as the poverty and social exclusion risk (23,7\% in 2008 and 2015 year). Moreover, the long-term unemployment rate considerably increased from 2,6\% in 2008 year to $4,5 \%$ in 2015 year (Eurostat, http) giving a pessimistic prognosis about future social cohesion. The situation justifies the necessity to search for some remedies. As economic activity and employment are the basic ways to increase both welfare as a social status of an individual and build socioeconomic cohesion, in the paper we investigate the most cohesive sectoral reallocation of labour.

\section{METHODOLOGY}

This paper uses Data Envelopment Analysis (DEA) as a linear programming method to measure the relative efficiency of the $28 \mathrm{EU}$ countries in transforming employment in different sectors into socioeconomic cohesion. Even though there is a general understanding of the efficiency as the relation of output to input which can be expressed as an output-input ratio (Kaasa, 2016, p. 12), different approaches are possible considering number and kinds of both inputs and outputs. The DEA method, proposed by Charnes, Cooper, and Rhodes (1978) allows assessing the efficiency of objects (Decision Making Units DMUs) when using multiple inputs to get multiple outputs and it does not require to specify functional relations between inputs and outputs. The DEA method may be oriented on inputs or on outputs. The first approach assumes minimizing inputs, while the second assumes maximizing outputs. In some DEA models, it is also possible not to assume any kind of orientation. When adopting input orientation, efficiency scores inform about the percentage of current inputs that should be used by an object to perform efficiently. However, the DEA allows measuring efficiency only in relative terms within a homogenous group of objects. It helps to identify the benchmarks as the best performing units and to compare them to the other units, which gain efficiency scores expressed as a percentage of the benchmarks results. Any change in a group of objects or inputs and outputs influence the results (Guzik, 2009).

This study analyses 28 countries that are members of the European Union. Although all of them have some distinct features in terms of geographical and scale conditions, demographics, historical experience or model of socioeconomic policy, concerning their EU memberships and a similar level of general development, they can be perceived as a quite homogenous group. Applying the DEA method allows identifying those EU countries that perform the best (those that are at the best practice production frontier) in terms of social cohesion when employing people in different economic sectors and those that have the most serious cohesive problems. 
Classical DEA-CCR model constitutes a starting point to many modifications. Non-radial efficiency model CCR-NR (Thanassoulis \& Dyson, 1992; Zhu, 1996) is one of them. In input-oriented version, it allows for different multipliers of each input and thus assumes that not all inputs are characterized by the same efficiency and substitution between them is possible (Guzik, 2009). The possibility of substitution between inputs is a special feature of structural changes in an economy experiencing modernization processes and it makes us adopt an input-oriented CCR-NR method of evaluation the cohesive efficiency of employment structures.

To assess how sectoral structure of employment influence socioeconomic cohesion in the EU countries, multiple inputs and outputs in the DEA model are applied. The data were extracted from Eurostat database and describe the most actual indicators available at the moment of writing the study (Eurostat, http).

Set of inputs reveals differences in the modernization of structures of employment that is generally characterized by tertiarisation and knowledge-intensity (also technological knowledge). Thus, the inputs are specified as employment per 100 inhabitants (this relation is counted to avoid disturbances resulting from the different scale of the economies) in 2015 year in four sectors:

- high and medium-high-technology manufacturing (hm);

- low and medium-low-technology manufacturing $(\mathrm{lm})$;

- knowledge-intensive services (kis);

- less knowledge-intensive services (lkis).

This specification allows to catch both processes: development of the service sector and appearance of the knowledge-based economy. Combining these trends results in comparisons of the four sectors. While tertiarisation process means a shift in employment towards both lkis and kis sectors, development of the knowledge-based economy is featured mainly by growing share of kis employment, however, with complementarity to $\mathrm{hm}$. Using DEA model helps us to compare each of these sectors' efficiency in terms of socioeconomic cohesion. Thus, we evaluate cohesive effects of modernization.

Although modernization is a process of changes observed in time we evaluate the most recent situation using data for 2015 year. It describes a current progress of each of the economies in the processes of tertiarisation and knowledge-intensification. In fact, structural changes are long-lasting phenomena and thus choosing the specified year should not influence results much. Moreover, the period since 2008 year was specified by serious disturbances caused by the crisis and in 2015 year the EU economies seemed to reveal the signs of recovery.

Outputs in our model reveal different dimensions of socioeconomic cohesion. As mentioned in section 2, two aspects are taken into account that put a strong link between social cohesion and employment: distribution of wealth and social networks and they are represented by:

- income quintile share ratio, that is the ratio of total equivalised disposable income received by the $20 \%$ of the population with the highest income (top quintile) to that received by the $20 \%$ of the population with the lowest income (lowest quintile) - 2015 year (quint);

- percentage of the population rating their satisfaction with personal relationships as high - 2013 year (sat).

The former field is reflected by an objective indicator, while the latter - in terms of subjective assessment of existing relationships. The indicators represent a pursuit to harmonise relationships between people and to equalize wealth distribution. As outputs in DEA model should increase their value while performing better, inversion of the first indicator was used.

These indicators are characterized by sufficient variation (that is usually specified at $15 \%$ level at least) between the $28 \mathrm{EU}$ countries (see Table 1). Other potential variables we considered were e.g. in the first 
dimension: Gini coefficient of equivalised disposable income, percentage of population at risk of poverty or social exclusion, percentage of population at risk (at persistent risk) of poverty (by different poverty threshold: $40 \%, 50 \%, 60 \%, 70 \%$ of median or mean equivalised income after social transfers), percentage of population under material deprivation (4 items or more) or long-term unemployment as percentage of active population, and in the second dimension: average rating of trust in others, percentage of population having someone to rely on in case of need. Unfortunately, they (or their modification into stimulants) does not fulfil the variation condition and thus did not reveal a potential to express differences between the EU countries.

Eventually, our model of CCR-NR input-oriented assumes 4 inputs and 2 outputs for 28 countries. This specification is consistent with a rule of a maximal number of variables that is expressed as: 3(Inputs+Outputs)<Objects (Nitkiewicz, 2014, p. 255). Descriptive statistics for the 6 variables are presented in Table 1.

Table 1

Descritpive statistics of inputs $\{\mathrm{I}\}$ and outputs $\{\mathrm{O}\}$ variables

\begin{tabular}{|l|c|c|c|c|c|c|}
\hline \multicolumn{1}{|c|}{ statistics } & $\mathrm{hm}\{\mathrm{I}\}$ & $\operatorname{lm}\{\mathrm{I}\}$ & $\mathrm{kis}\{\mathrm{I}\}$ & lkis $\{\mathrm{I}\}$ & sat $\{\mathrm{O}\}$ & quint $\{\mathrm{O}\}$ \\
\hline maximum & $\begin{array}{c}5,361409 \\
\text { (Czech Republic) }\end{array}$ & $\begin{array}{c}7,695757 \\
\text { (Czech Republic) }\end{array}$ & $\begin{array}{c}26,20198 \\
\text { (Sweden) }\end{array}$ & $\begin{array}{c}17,47327 \\
\text { (Cyprus) }\end{array}$ & $\begin{array}{c}60,3 \\
\text { (Ireland) }\end{array}$ & $\begin{array}{c}0,285714 \\
\text { (Slovakia) }\end{array}$ \\
\hline minimum & $\begin{array}{c}0,354188 \\
\text { (Cyprus) }\end{array}$ & $\begin{array}{c}1,598698 \\
\text { (Luxembourg) }\end{array}$ & $\begin{array}{c}9,370606 \\
\text { (Romania) }\end{array}$ & $\begin{array}{c}10,36705 \\
\text { (Romania) }\end{array}$ & $\begin{array}{c}14,6 \\
\text { (Bulgaria) }\end{array}$ & $\begin{array}{c}0,120482 \\
\text { (Romania) }\end{array}$ \\
\hline mean & 2,148332 & 4,533662 & 17,24966 & 13,32634 & 41,52857 & 0,210687 \\
\hline stand. dev. & 1,326445 & 1,57801 & 4,064595 & 1,575589 & 11,30448 & 0,049906 \\
\hline var. coeff. & $61,74 \%$ & $34,81 \%$ & $23,56 \%$ & $11,82 \%$ & $27,22 \%$ & $23,69 \%$ \\
\hline
\end{tabular}

Source: own calculations based on (Eurostat, http).

The four sectors reveal a different scale of employment in the EU countries, ranging from the average of 2,1 employees per 100 inhabitants in hm to 17,5 in kis. Moreover, especially in manufacturing sectors, there are strong differences between the economies. The Czech Republic employs proportionally the numerous group of persons in both kinds of manufacturing sectors. Sweden engages people mainly in kis, while lkis is a sector with relatively the highest proportion of employment in Cyprus. On the other hand, the smallest scale of employment in both kinds of services is observed in Romania, in $\mathrm{hm}$ - in Cyprus and in $\mathrm{lm}$ - in Luxembourg. Considering cohesive effects, the highest satisfaction from personal relationships characterizes Ireland and the most equal distribution of income specifies Slovakia. The poorest results are found in Bulgaria (in relational aspect) and Romania (in distributional aspect).

\section{EMPIRICAL RESULTS AND DISCUSSION}

The DEA application to assess the cohesive efficiency of employment reveals some interesting findings (Table 2). The general level of efficiency of the $28 \mathrm{EU}$ countries appears to be high, as the average is $86 \%$. Nevertheless, the result means that about $14 \%$ of employment does not generate cohesive effects. Variation between countries is moderate and suggests that there are no fundamental differences when comparing socioeconomic cohesion induced by employment. However, the promising efficiency scores are influenced by the fact that 12 countries were specified as a benchmark. Unfortunately, a numerous group of efficient objects is indicated as a typical weakness of the DEA method. The efficient ones appear to be: Belgium, Czech Republic, Ireland, Greece, Croatia, Cyprus, Luxembourg, Malta, Poland, Slovenia, Slovakia, and Finland. Many of them belong to the group of post-socialist countries and this kind of historical experience 
may strongly influence cohesion of society by its both: distributional and relational dimensions. However, between efficient countries, one can find Belgium or Luxemburg as well, what proves that post-socialism is not a key to explain the optimal results. Nevertheless, it shows that a social welfare model and institutional solutions may constitute a crucial factor for the cohesive efficiency of employment.

When analysing non-efficient countries, it is worth to mention relatively favourable results of UK, Netherlands, France, and Austria that gain scores above the average. Efficiency losses in the UK are only at about $8 \%$ level, in Netherlands and France at about 9\%, and in Austria at about 12\%. On the other hand, another 12 countries achieved results below the average and the poorest efficiency is observed in Bulgaria, Estonia, and Germany. In the first, only $50 \%$ of employment may be associated with cohesive gains, while in the others efficiency level is below $60 \%$ of the optimal. Cohesive problems are thus present in both the advanced economies (e.g. Germany) and in the catching-up countries.

Although 12 efficient countries were identified, in fact only a few of them create a real benchmark for other economies. The most important ones are Luxembourg that becomes a model for 11 other EU members and Ireland - for 10 of them. Additionally, practical solution to socioeconomic cohesion can be derived from Finland (that constitutes a benchmark for 6 countries) and Belgium (for 5). Even though they are fully efficient, Czech Republic, Greece, Croatia, Malta, and Slovakia, in fact, are not a benchmark for any other EU country.

Moreover, the analysis of an intensity of scale effects indicator (S) reveals that a scale of employment is favourable for socioeconomic cohesion. $\mathrm{S}$ indicator for 11 countries takes negative values and thus shows the existence of small scale inefficiency and only for 5 - positive values, additionally close to 0 . As the complementary to employment per capita are: unemployment, economic inactivity or demographic features of society (pre-working or post-working age), the scale of employment is directly connected with participation in social contacts and availability of earnings as the main source of incomes for a wider group of society. Romania, Bulgaria, Spain, and Italy are those countries that unveil the strongest inefficiency of the small scale of employment as they suffer from the most serious problems of unemployment. Thus the cohesive problems connected with exclusion from labour market are found in the poorest economies of both the "new" and the "old" members of the EU.

Sectoral reallocation of labour forces appears to be important for efficiency in gaining socioeconomic cohesion. The research proves that modernization is favourable for cohesive goals as the highest average efficiency is typical for a service sector (kis and also lkis) and the efficiency is higher for modern manufacturing $(\mathrm{hm})$ than for traditional one $(\mathrm{lm})$. Moreover, the results do not support the claims about the importance of all kinds of knowledge: embodied (connected with advanced equipment) and disembodied (reflected in a form of human capital). The first one is engaged mainly in hm, while kis bases mainly on human capital. Comparison of these sectors' efficiency suggests that a more cohesive form of knowledge is definitely human capital.

The average efficiency of kis reaches $98 \%$ and most countries (21) are fully efficient when assessing results of employment in this sector for socioeconomic cohesion. Moreover, it is a typical pattern as the variation is less than $5 \%$. Estonia is the least efficient country when considering kis employment, however, its efficiency losses are only 20\%. Relatively weak results are also observed in Sweden, UK, Spain and Portugal, Denmark and Germany (that is nearly fully efficient). Among all these countries the inefficiencies are connected mainly with the relational aspect of employment in kis. The UK constitutes the only exception as it experiences the most serious distributional inefficiencies of kis. 
Cohesive efficiency of employment - DEA scores for the 28EU countries

\begin{tabular}{|c|c|c|c|c|c|c|c|c|c|c|c|c|}
\hline & DMU & $\begin{array}{c}\text { efficiency } \\
\theta\end{array}$ & $\begin{array}{c}\text { efficienc } \\
\mathrm{y} \\
\theta \mathrm{hm} \\
\end{array}$ & \begin{tabular}{|c|} 
efficienc \\
$y$ \\
$\theta \mathrm{lm}$ \\
\end{tabular} & \begin{tabular}{|c|} 
efficienc \\
$y$ \\
$\theta$ kis \\
\end{tabular} & \begin{tabular}{|c|} 
efficienc \\
$\mathbf{y}$ \\
$\theta$ lkis \\
\end{tabular} & $\min \theta n$ & $\max \theta n$ & $\begin{array}{c}\text { var. coeff. } \\
\quad \theta n\end{array}$ & $\begin{array}{c}\text { scale effects } \\
\text { S }\end{array}$ & $\begin{array}{c}\text { benchmar } \\
\text { ks }\end{array}$ & \begin{tabular}{|c|}
$\begin{array}{c}\text { substitutio } \\
\text { n of inputs } \\
z\end{array}$ \\
\end{tabular} \\
\hline 1 & Belgium & $100,00 \%$ & $100,00 \%$ & $100,00 \%$ & $100,00 \%$ & $100,00 \%$ & $100,00 \%$ & $100,00 \%$ & $0,00 \%$ & & 5 & \\
\hline 2 & Bulgaria & $49,92 \%$ & $28,27 \%$ & $18,59 \%$ & $100,00 \%$ & $52,83 \%$ & $18,59 \%$ & $100,00 \%$ & $63,08 \%$ & $-0,27$ & $\begin{array}{c}1(0,17) \\
16(0,41) \\
\end{array}$ & 2,57 \\
\hline 3 & $\begin{array}{l}\text { Czech } \\
\text { Republic }\end{array}$ & $100,00 \%$ & $100,00 \%$ & $100,00 \%$ & $100,00 \%$ & $100,00 \%$ & $100,00 \%$ & $100,00 \%$ & $0,00 \%$ & & 0 & \\
\hline 4 & Denmark & $81,83 \%$ & $65,02 \%$ & $71,98 \%$ & $94,53 \%$ & $95,78 \%$ & $65,02 \%$ & $95,78 \%$ & $16,57 \%$ & 0,04 & $\begin{array}{c}7(0,67) \\
16(0,41)\end{array}$ & 1,27 \\
\hline 5 & Germany & $59,40 \%$ & $22,15 \%$ & $40,12 \%$ & $99,52 \%$ & $75,80 \%$ & $22,15 \%$ & $99,52 \%$ & $50,77 \%$ & $-0,05$ & $\begin{array}{c}7(0,41) \\
16(0,50)\end{array}$ & 2,36 \\
\hline 6 & Estonia & $56,51 \%$ & $16,65 \%$ & $31,53 \%$ & $80,62 \%$ & $97,24 \%$ & $16,65 \%$ & $97,24 \%$ & $59,04 \%$ & $-0,10$ & $\begin{array}{l}13(0,75) \\
16(0,07) \\
\end{array}$ & 2,83 \\
\hline 7 & Ireland & $100,00 \%$ & $100,00 \%$ & $100,00 \%$ & $100,00 \%$ & $100,00 \%$ & $100,00 \%$ & $100,00 \%$ & $0,00 \%$ & & 10 & \\
\hline 8 & Greece & $100,00 \%$ & $100,00 \%$ & $100,00 \%$ & $100,00 \%$ & $100,00 \%$ & $100,00 \%$ & $100,00 \%$ & $0,00 \%$ & & 0 & \\
\hline 9 & Spain & $67,21 \%$ & $75,28 \%$ & $46,80 \%$ & $92,53 \%$ & $54,24 \%$ & $46,80 \%$ & $92,53 \%$ & $26,73 \%$ & $-0,22$ & $\begin{array}{c}7(0,50) \\
16(0,14)\end{array}$ & 1,49 \\
\hline 10 & France & $91,47 \%$ & $82,59 \%$ & $90,52 \%$ & $100,00 \%$ & $92,78 \%$ & $82,59 \%$ & $100,00 \%$ & $6,79 \%$ & $-0,05$ & $\begin{array}{c}1(0,39) \\
16(0,20) \\
26(0,31) \\
\end{array}$ & 1,10 \\
\hline 11 & Croatia & $100,00 \%$ & $100,00 \%$ & $100,00 \%$ & $100,00 \%$ & $100,00 \%$ & $100,00 \%$ & $100,00 \%$ & $0,00 \%$ & & 0 & \\
\hline 12 & Italy & $66,45 \%$ & $54,72 \%$ & $50,10 \%$ & $100,00 \%$ & $60,97 \%$ & $50,10 \%$ & $100,00 \%$ & $29,73 \%$ & $-0,22$ & $\begin{array}{c}1(0,44) \\
16(0,01) \\
26(0,19) \\
\end{array}$ & 1,44 \\
\hline 13 & Cyprus & $100,00 \%$ & $100,00 \%$ & $100,00 \%$ & $100,00 \%$ & $100,00 \%$ & $100,00 \%$ & $100,00 \%$ & $0,00 \%$ & & 4 & \\
\hline 14 & Latvia & $78,07 \%$ & $65,03 \%$ & $47,26 \%$ & $100,00 \%$ & $100,00 \%$ & $47,26 \%$ & $100,00 \%$ & $29,22 \%$ & $-0,05$ & $\begin{array}{c}7(0,08) \\
13(0,67) \\
16(0,16) \\
\end{array}$ & 1,56 \\
\hline 15 & Lithuania & $82,62 \%$ & $87,79 \%$ & $42,83 \%$ & $100,00 \%$ & $99,84 \%$ & $42,83 \%$ & $100,00 \%$ & $28,44 \%$ & $-0,05$ & $\begin{array}{c}7(0,27) \\
13(0,63) \\
\end{array}$ & 1,56 \\
\hline 16 & Luxembourg & $100,00 \%$ & $100,00 \%$ & $100,00 \%$ & $100,00 \%$ & $100,00 \%$ & $100,00 \%$ & $100,00 \%$ & $0,00 \%$ & & 11 & \\
\hline 17 & Hungary & $80,02 \%$ & $62,39 \%$ & $75,33 \%$ & $100,00 \%$ & $82,37 \%$ & $62,39 \%$ & $100,00 \%$ & $16,97 \%$ & $-0,08$ & $\begin{array}{c}1(0,46) \\
24(0,35) \\
26(0,05) \\
\end{array}$ & 1,29 \\
\hline 18 & Malta & $100,00 \%$ & $100,00 \%$ & $100,00 \%$ & $100,00 \%$ & $100,00 \%$ & $100,00 \%$ & $100,00 \%$ & $0,00 \%$ & & 0 & \\
\hline 19 & Netherlands & $91,22 \%$ & $89,50 \%$ & $83,83 \%$ & $100,00 \%$ & $91,53 \%$ & $83,83 \%$ & $100,00 \%$ & $6,36 \%$ & 0,02 & $\begin{array}{c}1(0,31) \\
16(0,51) \\
26(0,23)\end{array}$ & 1,10 \\
\hline 20 & Austria & $88,11 \%$ & $91,18 \%$ & $75,89 \%$ & $100,00 \%$ & $85,38 \%$ & $75,89 \%$ & $100,00 \%$ & $9,95 \%$ & 0,01 & $\begin{array}{c}7(0,73) \\
24(0,24) \\
26(0,05) \\
\end{array}$ & 1,16 \\
\hline 21 & Poland & $100,00 \%$ & $100,00 \%$ & $100,00 \%$ & $100,00 \%$ & $100,00 \%$ & $100,00 \%$ & $100,00 \%$ & $0,00 \%$ & & 1 & \\
\hline 22 & Portugal & $70,42 \%$ & $47,70 \%$ & $40,59 \%$ & $93,37 \%$ & $100,00 \%$ & $40,59 \%$ & $100,00 \%$ & $37,63 \%$ & $-0,08$ & \begin{tabular}{|c}
$7(0,18) 13$ \\
$(0,68)$ \\
\end{tabular} & 1,76 \\
\hline 23 & Romania & $63,84 \%$ & $52,15 \%$ & $36,74 \%$ & $100,00 \%$ & $66,46 \%$ & $36,74 \%$ & $100,00 \%$ & $36,62 \%$ & $-0,29$ & $\begin{array}{c}7(0,38) \\
21(0,15) \\
24(0,02) \\
\end{array}$ & 1,72 \\
\hline 24 & Slovenia & $100,00 \%$ & $100,00 \%$ & $100,00 \%$ & $100,00 \%$ & $100,00 \%$ & $100,00 \%$ & $100,00 \%$ & $0,00 \%$ & & 3 & \\
\hline 25 & Slovakia & $100,00 \%$ & $100,00 \%$ & $100,00 \%$ & $100,00 \%$ & $100,00 \%$ & $100,00 \%$ & $100,00 \%$ & $0,00 \%$ & & 0 & \\
\hline 26 & Finland & $100,00 \%$ & $100,00 \%$ & $100,00 \%$ & $100,00 \%$ & $100,00 \%$ & $100,00 \%$ & $100,00 \%$ & $0,00 \%$ & & 6 & \\
\hline 27 & Sweden & $83,43 \%$ & $55,43 \%$ & $89,46 \%$ & $88,83 \%$ & $100,00 \%$ & $55,43 \%$ & $100,00 \%$ & $20,09 \%$ & 0,02 & $\begin{array}{c}7(0,04) \\
16(0,58) \\
26(0,43)\end{array}$ & 1,34 \\
\hline 28 & \begin{tabular}{|l|} 
United \\
Kingdom \\
\end{tabular} & $92,39 \%$ & $100,00 \%$ & $85,33 \%$ & $91,09 \%$ & $93,13 \%$ & $85,33 \%$ & $100,00 \%$ & $5,68 \%$ & 0,03 & $\begin{array}{c}7(0,75) \\
16(0,31) \\
\end{array}$ & 1,09 \\
\hline & mean & $85,82 \%$ & $78,42 \%$ & $75,96 \%$ & $97,87 \%$ & $91,01 \%$ & & & & & & $1,16^{*}$ \\
\hline & std. dev. & $15,74 \%$ & $26,25 \%$ & $26,91 \%$ & $4,56 \%$ & $14,65 \%$ & & & & & & \\
\hline & var. coeff. & $18,34 \%$ & $33,47 \%$ & $35,42 \%$ & $4,66 \%$ & $16,10 \%$ & & & & & & \\
\hline
\end{tabular}

*calculated basing on the mean scores for the 28EU countries

Source: own calculations based on (Eurostat, http). 
The average efficiency of lkis is also at a high level of $91 \%$. The coefficient of variation equals $16 \%$, so the differences between countries are more serious. There are 15 benchmarks, however, the least performing economy (Bulgaria) achieves only 53\% of optimal efficiency. Spain, Italy, and Romania are also in a group of laggards. The smallest losses are found in Lithuania, Estonia, and Denmark.

High-efficiency scores of services could be explained by the personality of service relations which is a typical characteristic of these activities. It can enhance the relational dimension of cohesion. Moreover, high heterogeneity of the service sector results in a possibility of employment for many groups of workers, specified by different level of human capital. The feature of inclusivity may equalize income distribution.

Losses in efficiency are more serious in manufacturing sectors, especially in $1 \mathrm{~m}$. They affect even $1 / 4$ of employment inputs at average. Thus, engagement in manufacturing in comparison to service employment generally limits multidimensional social cohesion - increases income inequality and reduces satisfaction with personal contacts.

An average cohesive efficiency of $\mathrm{hm}$ is at $78 \%$ level. There is a strong differentiation between economies, as the coefficient of variation equals 33\%. Optimal efficiency is a characteristic of 13 countries, while the least efficient is Estonia that gains only $16 \%$ of full efficiency. Germany and Bulgaria also achieve weak results and their efficiency losses exceed $70 \%$. It is worth to stress that in these economies the most serious inefficiencies of $\mathrm{hm}$ employment are found in distributional dimension.

Finally, the poorest cohesive effects of employment are found in $1 \mathrm{~m}$ where the average efficiency reaches only $75 \%$ and goes along with strong differentiation between countries (35\% variation). 12 countries are fully efficient. Bulgaria gains the weakest results (only about 19\%) and then Estonia and Romania (30$40 \%)$.

As there are differences in efficiency of each sector some structural changes are favourable for socioeconomic cohesion. They are connected with employment shift from less into more efficient sectors, namely from manufacturing into services. This information can be derived from indicators of substitution - the detailed ones (calculated as the relation of efficiency scores in two sectors under comparison) and the synthetic one ( $\mathrm{z}$ - calculated as a geometric mean of the detailed relations).

As the indicators basing on the average efficiency scores for the 28EU countries show there is a need for general substitution of $16 \%$ of labour forces. Detailed directions can be described as a movement from $\mathrm{lm}$ into kis and the level of employment in low-tech should achieve $78 \%$ of the current level. Another important movement is a shift from $\mathrm{hm}$ into kis (substitution: 0,8 ). Additionally, reallocation of employees from both kinds of manufacturing into lkis (substitution $\operatorname{lm}$ (lkis): 0,83 and hm(lkis): 0,86) would be desirable from the point of view of the cohesive goal. Moreover, there would be favourable that employment move from lkis into kis (substitution kis(lkis): 1,08) and finally from $\mathrm{lm}$ into $\mathrm{hm}$ (substitution $\mathrm{hm}(\mathrm{lm}): 1,03)$.

Comparing the inefficient EU countries it is possible to point out economies in a need for the most serious employment shift. Estonia, Bulgaria, and Germany are such countries, while in the United Kingdom, Netherlands and France the substitution between sectors requires shifts in employment not higher than $10 \%$.

It is worth to specify the optimal structure of employment considering its cohesive results. Even though it is unique for each country, some patterns are reflected by the most often appearing benchmarks: Luxembourg and Ireland. In the first, more than $60 \%$ of labour force is engaged in kis and nearly $1 / 3$ in lkis, while hm employs only $1 \%$ and $\mathrm{lm}-4 \%$. In Ireland as well kis dominate with $51 \%$ of employment and lkis follow with a little above $1 / 3$ of employment. Although manufacturing engages a little more labour forces than in Luxembourg, $\mathrm{hm}$ appears to be the smallest sector with $6 \%$ of employment. 
Efficiency of employment in terms of distributive and relational dimensions of cohesion

\begin{tabular}{|c|c|c|c|c|c|c|c|c|c|c|c|c|c|}
\hline & \multirow[b]{2}{*}{ DMU } & \multicolumn{6}{|c|}{ Distributive cohesion (quint) } & \multicolumn{6}{|c|}{ Relational cohesion (sat) } \\
\hline & & \begin{tabular}{|c|} 
benchmark \\
$\mathrm{s}$ \\
\end{tabular} & $\begin{array}{c}\theta \text { quint } \\
\text { hm }\end{array}$ & \begin{tabular}{|c|}
$\begin{array}{c}\theta \text { quint } \\
\operatorname{lm}\end{array}$ \\
\end{tabular} & \begin{tabular}{|c|}
$\theta$ quint \\
kis
\end{tabular} & $\begin{array}{c}\theta \text { quint } \\
\text { lkis }\end{array}$ & $\theta$ quint & \begin{tabular}{|c|} 
benchmark \\
$\mathrm{s}$
\end{tabular} & $\begin{array}{c}\theta \text { sat } \\
\mathrm{hm}\end{array}$ & $\theta$ sat $\operatorname{lm}$ & $\theta$ sat kis & $\begin{array}{l}\theta \text { sat } \\
\text { lkis }\end{array}$ & $\theta$ sat \\
\hline 1 & Belgium & 17 & $100,00 \%$ & $100,00 \%$ & $100,00 \%$ & $100,00 \%$ & $100,00 \%$ & $7(0,47)$ & $55,50 \%$ & $36,27 \%$ & $45,82 \%$ & $51,69 \%$ & $47,32 \%$ \\
\hline 2 & Bulgaria & $\begin{array}{c}1(0,17) \\
16(0,41)\end{array}$ & $28,27 \%$ & $18,59 \%$ & $100,00 \%$ & $52,83 \%$ & $49,92 \%$ & $7(0,24)$ & $32,24 \%$ & $9,44 \%$ & $34,40 \%$ & $23,61 \%$ & $24,92 \%$ \\
\hline 3 & Czech Republic & $\begin{array}{c}1(0,04) \\
25(0,97) \\
\end{array}$ & $86,44 \%$ & $81,10 \%$ & $100,00 \%$ & $93,66 \%$ & $90,30 \%$ & $7(0,79)$ & $32,19 \%$ & $26,65 \%$ & $96,41 \%$ & $80,81 \%$ & $59,02 \%$ \\
\hline 4 & Denmark & $\begin{array}{c}1(0,19) \\
16(0,83)\end{array}$ & $26,40 \%$ & $59,60 \%$ & $100,00 \%$ & $86,74 \%$ & $68,19 \%$ & $7(0,94)$ & $83,09 \%$ & $73,51 \%$ & $74,73 \%$ & $85,81 \%$ & $79,29 \%$ \\
\hline 5 & Germany & $\begin{array}{c}1(0,21) \\
16(0,66) \\
\end{array}$ & $12,82 \%$ & $37,79 \%$ & $100,00 \%$ & $69,46 \%$ & $55,02 \%$ & $7(0,75)$ & $33,42 \%$ & $41,47 \%$ & $70,54 \%$ & $64,23 \%$ & $52,42 \%$ \\
\hline 6 & Estonia & $16(0,69)$ & $14,07 \%$ & $15,01 \%$ & $94,67 \%$ & $59,07 \%$ & $45,71 \%$ & $7(0,61)$ & $76,24 \%$ & $21,48 \%$ & $65,43 \%$ & $55,85 \%$ & $54,75 \%$ \\
\hline 7 & Ireland & $\begin{array}{c}1(0,54) \\
16(0,35) \\
\end{array}$ & $51,55 \%$ & $91,68 \%$ & $100,00 \%$ & $81,74 \%$ & $81,24 \%$ & 20 & $100,00 \%$ & $100,00 \%$ & $100,00 \%$ & $100,00 \%$ & $100,00 \%$ \\
\hline 8 & Greece & 0 & $100,00 \%$ & $100,00 \%$ & $100,00 \%$ & $100,00 \%$ & $100,00 \%$ & $13(0,56)$ & $44,57 \%$ & $62,34 \%$ & $76,72 \%$ & $80,51 \%$ & $66,04 \%$ \\
\hline 9 & Spain & $\begin{array}{c}1(0,13) \\
16(0,47) \\
\end{array}$ & $27,45 \%$ & $36,97 \%$ & $100,00 \%$ & $48,03 \%$ & $53,11 \%$ & $7(0,60)$ & $85,70 \%$ & $47,36 \%$ & $80,59 \%$ & $50,94 \%$ & $66,15 \%$ \\
\hline 10 & France & $\begin{array}{c}1(0,72) \\
16(0,19) \\
\end{array}$ & $80,38 \%$ & $87,88 \%$ & $100,00 \%$ & $92,89 \%$ & $90,29 \%$ & $7(0,56)$ & $70,56 \%$ & $47,06 \%$ & $57,32 \%$ & $62,79 \%$ & $59,43 \%$ \\
\hline 11 & Croatia & 1 & $100,00 \%$ & $100,00 \%$ & $100,00 \%$ & $100,00 \%$ & $100,00 \%$ & $13(0,65)$ & $19,11 \%$ & $37,77 \%$ & $85,36 \%$ & $99,13 \%$ & $60,34 \%$ \\
\hline 12 & Italy & $\begin{array}{c}1(0,65) \\
16(0,01) \\
\end{array}$ & $53,67 \%$ & $48,98 \%$ & $100,00 \%$ & $61,03 \%$ & $65,92 \%$ & $7(0,37)$ & $36,10 \%$ & $21,45 \%$ & $54,77 \%$ & $37,81 \%$ & $37,53 \%$ \\
\hline 13 & Cyprus & 0 & $100,00 \%$ & $100,00 \%$ & $100,00 \%$ & $100,00 \%$ & $100,00 \%$ & 5 & $100,00 \%$ & $100,00 \%$ & $100,00 \%$ & $100,00 \%$ & $100,00 \%$ \\
\hline 14 & Latvia & $16(0,66)$ & $33,34 \%$ & $20,59 \%$ & $97,12 \%$ & $55,34 \%$ & $51,60 \%$ & 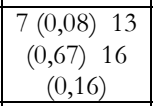 & $65,03 \%$ & $47,26 \%$ & $100,00 \%$ & $100,00 \%$ & $78,07 \%$ \\
\hline 15 & Lithuania & $16(0,57)$ & $22,04 \%$ & $15,30 \%$ & $88,59 \%$ & $48,08 \%$ & $43,50 \%$ & $\begin{array}{c}7(0,27) 13 \\
(0,63)\end{array}$ & $87,79 \%$ & $42,83 \%$ & $100,00 \%$ & $99,84 \%$ & $82,62 \%$ \\
\hline 16 & Luxembourg & 16 & $100,00 \%$ & $100,00 \%$ & $100,00 \%$ & $100,00 \%$ & $100,00 \%$ & 3 & $100,00 \%$ & $100,00 \%$ & $100,00 \%$ & $100,00 \%$ & $100,00 \%$ \\
\hline 17 & Hungary & $\begin{array}{c}1(0,57) \\
25(0,29) \\
\end{array}$ & $62,45 \%$ & $71,80 \%$ & $100,00 \%$ & $84,20 \%$ & $79,61 \%$ & $7(0,56)$ & $31,39 \%$ & $27,70 \%$ & $68,07 \%$ & $59,97 \%$ & $46,78 \%$ \\
\hline 18 & Malta & $\begin{array}{c}1(0,60) \\
16(0,35)\end{array}$ & $88,67 \%$ & $65,24 \%$ & $100,00 \%$ & $82,01 \%$ & $83,98 \%$ & 0 & $100,00 \%$ & $100,00 \%$ & $100,00 \%$ & $100,00 \%$ & $100,00 \%$ \\
\hline 19 & Netherlands & $\begin{array}{c}1(0,55) \\
16(0,51) \\
\end{array}$ & $87,44 \%$ & $81,98 \%$ & $100,00 \%$ & $91,59 \%$ & $90,25 \%$ & $\begin{array}{c}7(0,08) \quad 16 \\
(0,90)\end{array}$ & $35,10 \%$ & $49,87 \%$ & $100,00 \%$ & $85,23 \%$ & $67,55 \%$ \\
\hline 20 & Austria & $\begin{array}{c}1(0,85) \\
16(0,08)\end{array}$ & $54,51 \%$ & $63,76 \%$ & $100,00 \%$ & $74,40 \%$ & $73,17 \%$ & $7(0,98)$ & $72,04 \%$ & $53,63 \%$ & $99,23 \%$ & $84,87 \%$ & $77,44 \%$ \\
\hline 21 & Poland & \begin{tabular}{|c|}
$1(0,43)$ \\
$11(0,04) 25$ \\
$(0,30)$
\end{tabular} & $100,00 \%$ & $59,14 \%$ & $100,00 \%$ & $81,41 \%$ & $85,14 \%$ & 1 & $100,00 \%$ & $100,00 \%$ & $100,00 \%$ & $100,00 \%$ & $100,00 \%$ \\
\hline 22 & Portugal & $\begin{array}{c}1(0,20) \\
16(0,49) \\
\end{array}$ & $42,21 \%$ & $24,15 \%$ & $100,00 \%$ & $59,14 \%$ & $56,38 \%$ & $\begin{array}{c}7(0,18) \quad 13 \\
(0,68)\end{array}$ & $47,70 \%$ & $40,59 \%$ & $93,37 \%$ & $100,00 \%$ & $70,42 \%$ \\
\hline 23 & Romania & $1(0,46)$ & $35,71 \%$ & $28,66 \%$ & $94,28 \%$ & $53,23 \%$ & $52,97 \%$ & \begin{tabular}{|c|}
$7(0,39) \quad 21$ \\
$(0,16)$ \\
\end{tabular} & $50,66 \%$ & $36,47 \%$ & $100,00 \%$ & $66,73 \%$ & $63,47 \%$ \\
\hline 24 & Slovenia & 1 & $100,00 \%$ & $100,00 \%$ & $100,00 \%$ & $100,00 \%$ & $100,00 \%$ & 0 & $100,00 \%$ & $100,00 \%$ & $100,00 \%$ & $100,00 \%$ & $100,00 \%$ \\
\hline 25 & Slovakia & 3 & $100,00 \%$ & $100,00 \%$ & $100,00 \%$ & $100,00 \%$ & $100,00 \%$ & $7(0,72)$ & $33,41 \%$ & $29,63 \%$ & $89,23 \%$ & $79,09 \%$ & $57,84 \%$ \\
\hline 26 & Finland & $\begin{array}{c}1(1,00) \\
24(0,05)\end{array}$ & $97,99 \%$ & $95,79 \%$ & $99,50 \%$ & $100,00 \%$ & $98,32 \%$ & $7(0,81)$ & $83,81 \%$ & $54,48 \%$ & $75,04 \%$ & $84,57 \%$ & $74,48 \%$ \\
\hline 27 & Sweden & $\begin{array}{c}1(0,43) \\
16(0,64)\end{array}$ & $47,91 \%$ & $83,03 \%$ & $90,14 \%$ & $100,00 \%$ & $80,27 \%$ & $7(0,78)$ & $78,23 \%$ & $66,93 \%$ & $55,22 \%$ & $77,93 \%$ & $69,58 \%$ \\
\hline 28 & United Kingdom & $16(0,83)$ & $16,87 \%$ & $46,36 \%$ & $84,16 \%$ & $69,34 \%$ & $54,18 \%$ & \begin{tabular}{|c|}
$7(0,75) \quad 16$ \\
$(0,31)$
\end{tabular} & $100,00 \%$ & $85,33 \%$ & $91,09 \%$ & $93,13 \%$ & $92,39 \%$ \\
\hline & mean & & $63,22 \%$ & $65,48 \%$ & $98,16 \%$ & $80,15 \%$ & $76,75 \%$ & & $66,21 \%$ & $55,70 \%$ & $82,62 \%$ & $79,45 \%$ & $70,99 \%$ \\
\hline & std. dev. & & $32,40 \%$ & $30,44 \%$ & $4,02 \%$ & $18,66 \%$ & $19,92 \%$ & & $27,17 \%$ & $27,94 \%$ & $19,26 \%$ & $21,17 \%$ & $20,26 \%$ \\
\hline & var. coeff. & & $51,24 \%$ & $46,49 \%$ & $4,10 \%$ & $23,28 \%$ & $25,95 \%$ & & $41,03 \%$ & $50,16 \%$ & $23,31 \%$ & $26,64 \%$ & $28,54 \%$ \\
\hline
\end{tabular}

Source: own calculations based on (Eurostat, http). 
Moreover, comparison of sectoral efficiency in both dimension of socioeconomic cohesion taken separately reveals some important information. As presented in Table 3 the average better results are achieved in distributional dimension, however, the differences are not high (77\% and $71 \%$ of full efficiency). What's more important, the compound cohesiveness is specified by higher efficiency of employment than both aspects taken separately. This suggests that it is better to simultaneously support equality of income distribution and favourable social relationships than to focus attention only on a chosen dimension.

Sectors differ when comparing their efficiency in both aspects of cohesion. Although kis appears the most efficient in both fields they efficiency is close to $100 \%$ in income distribution and reaches only about $83 \%$ when considering social networks. Thus cohesiveness of kis is mainly due to its inclusive employment that allows gaining incomes by different groups of people. Lkis takes the second position in both cohesive aspects and their efficiency is similar (about 80\% level). As the relational efficiency of both kinds of services is comparable it is possible to stress the positive role of human capital for distribution. Moreover, more favourable for personal relations is employment in $\mathrm{hm}$, while in limiting income inequalities it is the least efficient sector. This observation suggests that advanced technology usage is generally less cohesive as brings economic benefits only for a limited group of people inducing income inequalities.

The best performing countries when considering satisfaction with social ties are Ireland, Cyprus, Luxembourg, Poland and Malta and Slovenia, however, the most important benchmark is constituted by Ireland. This results may be influenced by a traditional social construction in Ireland with strong roots in religion and national identity. Focusing on distributional aspects 7 countries reveal full efficiency (Belgium, Luxembourg, Slovakia, Croatia, Slovenia, Greece, and Cyprus), but Belgium and Luxembourg are the most often benchmarks. This observation suggests that equal distribution is achieved at a high level of national income and may be induced by redistribution and a state care affordable for the richest economies.

The poorest performers in subjective dimension are Bulgaria and Italy. In objective terms, the weakest results are found in Lithuania, Estonia, and Bulgaria. Thus it may be stressed that the Baltic countries experience social tensions connected with income inequality, however, they are also present in the poorest economies such as Bulgaria. Generally, less developed Bulgaria suffers also with a lack of satisfying social ties, but this problem can be observed in "the old" EU members like Italy as well. The unemployment problems may be connected with such results.

Summing up, it is worth to stress that the most cohesive results of employment in the EU countries are observed in services, especially in the knowledge-intensive services. Thus the modernization characterized by the tertiarisation trend seems to be favourable for socioeconomic cohesion. The results are consistent with research presented from the purely economic perspective (e.g. Margaritis et al., 2007; Maudos et al., 2000; Kosmalski, 2012), where the most positive effects for GDP per capita level or aggregate productivity growth are attributed to tertiary sectors' employment. Nevertheless, the paper complements these findings with the social dimension trying to fulfil the identified research gap.

\section{CONCLUSION}

The main findings of the study support the view that modernization of a structure of employment is generally favourable for socioeconomic cohesion. Its directions connected with reallocation of the labour force from manufacturing into services and from less into more knowledge-intensive and high-technology based sectors, enhance cohesiveness in terms of more equal wealth distribution and satisfying personal relationships. Moreover, the results suggest that its more important to support the development of any kinds of services than to focus on high and medium-high technology manufacturing, at least when the expected goals are specified in terms of cohesion and are not limited to production objectives. Thus, the study 
contributes somehow to the discussion about reindustrialization, revealing support for the deindustrialization arguments.

Some other interesting findings are connected with different aspects of knowledge usage. While knowledge-intensive services base mainly on disembodied knowledge in a form of human capital and high and medium-high technology manufacturing takes advantage of mainly technical embodied knowledge, they reveal different cohesive results. Thus human capital may be perceived as a more cohesive form of knowledge than embodied technology.

The cohesive results of employment in service sectors are undoubtedly connected with the personality of service relations that is listed as a main classical feature of these activities. Additionally, the positive influence of employment in service sectors for the distributional dimension may be induced by the heterogeneity of the sector enabling to engage employees with a different level of human capital and thus revealing more inclusive character. The two dimensions of social cohesion are complementing each other as the multidimensional cohesive goals are at the average fulfiled with higher efficiency than taken separately. Thus, it may be stressed that to enhance cohesion, politics must be simultaneously focused on its many aspects. As important as objective results such as income distribution is the subjective perception of social relations in the economy such as satisfaction with social ties.

Nevertheless, it is important to focus the cohesive policy in the EU on new workplaces creation, especially in new sectoral growth poles that can mainly be found within the knowledge-intensive services. The condition to realise an aim of equal and harmonized society is to invest in human capital and engage it in production. It is especially a task in the post-crisis period when public funds on social needs are limited while the problems of long-term unemployment and economic inactivity may negatively influence an equal distribution, social inclusion, and personal relationships.

\section{ACKNOWLEDGEMENT}

The publication has been prepared at University of Rzeszów within statutory activities financially supported by the Ministry of Science and Higher Education (MNiSW) in Poland.

\section{REFERENCES}

Andrews, R. (2014). Coordinating for Cohesion: The Contribution of Public Management to the Cohesiveness of Society. Public Performance \& Management Review, 37(4), 705-721. doi:10.2753/PMR1530-9576370408.

Antonelli, C., \& Fassio, C. (2016). Globalization and the Knowledge-Driven Economy. Economic Development Quarterly, 30(1), 3-14. doi:10.1177/0891242415617239.

Badunenko, O., \& Romero\&Avila, D. (2010). Productivity Growth across Industries and Regions: A Production\&Frontier Approach Applied to the Spanish Case. Retrieved 09/10/2016 from http://www.alde.es/fotosbd/120620151100331636.pdf.

Charnes, A., Cooper, W. W., \& Rhodes, E. (1979). Measuring the efficiency of decision-making units. European journal of operational research, 3(4), 339.

Clark, C. (1940). The Conditions of Economic Progress. London, Macmillan and Co. Ltd.

De Backer, K., Desnoyers-James, I., \& Moussiegt, L. (2015). 'Manufacturing or Services - That is (not) the Question': The Role of Manufacturing and Services in OECD Economies. OECD Science, Technology and Industry Policy Papers, 19, OECD Publishing, doi:10.1787/5js64ks09dmn-en.

De Serres, A., Scarpetta, S., \& De la Maisonneuve, C. (2002). Sectoral Shifts in Europe and the United States: How They Affect Aggregate Labour Shares and the Properties of Wage Equations. OECD Economics Department Working Papers, 326, OECD Publishing, doi:10.1787/763626062738.

Dekker, K., \& Bolt, G. (2005). Social cohesion in post-war estates in the Netherlands: Differences between socioeconomic and ethnic groups. Urban studies, 42(13), 2447-2470. doi:10.1080/00420980500380360. 
Diewert, W. E. (2015). Decompositions of productivity growth into sectoral effects. Journal of Productivity Analysis, 43(3), 367-387. doi: 10.1007/s11123-014-0392-0.

Drucker, J. (2014). An evaluation of competitive industrial structure and regional manufacturing employment change. Retrieved 09/10/2016 from http://works.bepress.com/jidrucker/11.

Eurostat, Employment in technology and knowledge-intensive sectors at the national level, by sex (from 2008 onwards, NACE Rev. 2) [htec_emp_nat2]. Retrieved 18/12/2016 from http://ec.europa.eu/eurostat/data/database.

Eurostat, Inequality of income distribution - Income quintile share ratio [tsdsc260]. Retrieved 09/02/2017 from http://ec.europa.eu/eurostat/data/database.

Eurostat, Percentage of the population rating their satisfaction as high, medium or low by domain, sex, age and educational attainment level [ilc_pw05]. Retrieved 06/11/2016 from http://ec.europa.eu/eurostat/data/database.

Eurostat, Population on 1 January by age and sex [demo_pjan]. Retrieved 18/12/2016 from http://ec.europa.eu/eurostat/data/database.

Fisher, A.B.G. (1935). The Clash of Progress and Security. London, McMillan.

Fourastié, J. (1949). Le Grand Espoir du XXe siècle. Progrès technique, progrès économique, progrès social. Paris, Presses Universitaires de France.

Ghani, E., \& Kharas, H. (2010). The Service Revolution. Economic Premise, 14, May.

Ghani, E., Goswami, A. G., \& Kharas, H. (2012). Service with a Smile. Economic Premise, 96, 1-6.

Guzik, B. (2009). Podstawowe modele DEA w badaniu efektywności gospodarczej i spotecznej. Poznań, Wydawnictwo Uniwersytetu Ekonomicznego w Poznaniu.

Hoyman, M., McCall, J., Paarlberg, L., \& Brennan, J. (2016). Considering the Role of Social Capital for Economic Development Outcomes in US Counties. Economic Development Quarterly, 30(4), 342-357. doi:10.1177/0891242416659135.

Hulse, K., \& Stone, W. (2007). Social cohesion, social capital and social exclusion: a cross cultural comparison. Policy Studies, 28(2), 109-128. doi 10.1080/01442870701309049.

Kaasa, A. (2016). Social Capital, Institutional Quality and Productivity: Evidence from European Regions. Economics \& Sociology, 9(4), 11-26. doi:10.14254/2071-789X.2016/9-4/1.

Kearns, A., \& Forrest, R. (2000). Social cohesion and multilevel urban governance. Urban studies, 37(5-6), 995-1017.

Kemeny, T., \& Storper, M. (2015). Is specialization good for regional economic development?. Regional Studies, 49(6), 1003-1018. doi: 10.1080/00343404.2014.899691.

Kleer, J. (2012). Kulturowe uwarunkowania modernizacji [in:] Gospodarka Polski 1990-2011. Tom 3. Droga do spójności społecそno-ekonomicznej, ed. M.G. Woźniak, Warszawa, Wydawnictwo Naukowe PWN, 103-125.

Kohl, H. (2015). Convergence and divergence-10 years since EU enlargement. Transfer: European Review of Labour and Research, 21(3), 285-311. doi: 10.1177/1024258915585939.

Kosiel, M.W. (2012). Spójność społeczna - definicje, uwarunkowania, wskaźniki i strategie w Unii Europejskiej oraz Ameryce Lacińskiej. Ameryka Lacińska, 1 (75), pp. 26-42.

Roman, K. (2012). Przyczyny nierówności technologicznych w polskich województwach w latach 1998-2008. Studia Regionalne i Lokalne, 1(47), 43-68.

Kucera, D., \& Roncolato, L. (2014). Structure Matters: Sectoral Drivers of Growth and the Labour ProductivityEmployment Relationship. Beyond Macroeconomic Stability: Structural Transformation and Inclusive Development, 133.

Kuznets, S., \& Murphy, J. T. (1966). Modern economic growth: Rate, structure, and spread (Vol. 2). New Haven: Yale University Press.

Lechevalier, S. (2015). Globalization and labor market outcomes: de-industrialization, job security, and wage inequalities-introduction by guest editor. Review of World Economics, 151(3), 405-408. doi:10.1007/s10290-0150222-0.

Loayza, N., \& Raddatz, C. E. (2006). The composition of growth matters for poverty alleviation (Vol. 4077). World Bank Publications.

Loktieva, I. (2016). Approaches to Empirical Analysis of Social Exclusion: International Comparison. Economics \& Sociology, 9(2), 148-157. doi:10.14254/2071-789X.2016/9-2/10.

Margaritis, D., Färe, R., \& Grosskopf, S. (2007). Productivity, convergence and policy: a study of OECD countries and industries. Journal of Productivity Analysis, 28(1-2), 87-105. doi:10.1007/s11123-007-0044-8. 
Maudos, J., Pastor, J. M., \& Serrano, L. (2000). Efficiency and productive specialization: An application to the Spanish regions. Regional Studies, 34(9), 829-842.

McCann, Ph., \& Ortega-Argilés, R. (2011). Smart Specialisation, Regional Growth and Applications to EU Cohesion Policy. Economic Geography Working Paper, Faculty of Spatial Sciences, University of Groningen.

Mucha-Leszko, B. (2016). Polityka społeczna jako instrument spójności Unii Europejskiej. Nierówności społeczne a wærost gospodarczy, 3(47), 193-204. doi:10.15584/nsawg.2016.3.14.

Nitkiewicz, T., Pachura, P., \& Reid, N. (2014). An appraisal of regional intellectual capital performance using Data Envelopment Analysis. Applied Geography, 53, 246-257. doi:10.1016/j.apgeog.2014.06.011.

O’Leary, E. (2006). The Role of Structural Change in Productivity Convergence Among EU Regions. Retrieved 17/02/2017 from https://www.ucc.ie/en/media/academic/economics/documents/research/wp07-02.pdf.

O'Leary, E., \& Webber, D. J. (2015). The role of structural change in European regional productivity growth. Regional Studies, $49(9), 1548-1560$.

Paunov, C. (2013). Innovation and inclusive development: a discussion of the main policy issues. OECD Science, Technology and Industry Working Papers, 2013(1), 0_1. doi:10.1787/5k4dd1rvsnjj-en.

Peneder, M., Kaniovski, S., \& Dachs, B. (2001). What Follows Tertiarisation? Structural Change and the Role of Knowledge-Based Services. WIFO Working Papers, No. 146.

Perroux, F. (1955). Note sur la nation de pôle de criossance. Ekonomie Appliquée, no. 1 and 2.

Sassi, M. (2011). Convergence across the EU regions: Economic composition and structural transformation. International Advances in Economic Research, 17(1), 101-115. doi:10.1007/s11294-010-9286-8.

Thanassoulis, E., \& Dyson, R. G. (1992). Estimating preferred target input-output levels using data envelopment analysis. European Journal of Operational Research, 56(1), 80-97.

Wojnar, K. (2011). Wpływ polityki spójności na spójność społeczną polskich miast-wnioski z badań ewaluacyjnych. Studia Regionalne i Lokalne, (numer specjalny/special issue), 67-83.

Wolman, H., Stokan, E., \& Wial, H. (2015). Manufacturing Job Loss in US Deindustrialized Regions-Its Consequences and Implications for the Future: Examining the Conventional Wisdom. Economic Development Quarterly, 29(2), 102-112. doi:10.1177/0891242414566865.

Wolman, H., Wial, H., \& Hill, E. (2015). Introduction to Focus Issue on Deindustrialization, Manufacturing Job Loss, and Economic Development Policy. Economic Development Quarterly, 29(2), 99-101. doi:10.1177/0891242414567055.

Woźniak, M.G. (2012a). Oblicza modernizacji [in:] Gospodarka Polski 1990-2011. Tom 3. Droga do spójności spotecznoekonomicznej, ed. M.G. Woźniak, Warszawa, Wydawnictwo Naukowe PWN, 73-101.

Woźniak, M.G. (2012b). Teoretyczne i praktyczne kwestie budowy spójności społeczno-ekonomicznej dla gospodarki innowacyjnej [in:] Gospodarka Polski 1990-2011. Tom 3. Droga do spójności społeczno-ekonomicznej, ed. M.G. Woźniak, Warszawa, Wydawnictwo Naukowe PWN, 13-54.

Zhu, J. (1996). Data envelopment analysis with preference structure. Journal of the Operational Research Society, 47(1), 136150. 